Article

\title{
Social Class and Child Welfare: Intertwining Issues of Redistribution and Recognition
}

\author{
Halvor Fauske ${ }^{1}$, Bente Heggem Kojan ${ }^{2, *}$ and Anita Skårstad Storhaug ${ }^{2}$ \\ 1 Department of Social Work, Inland Norway University of Applied Sciences, N2418 Elverum, Norway; \\ halvor.fauske@inn.no \\ 2 Department of Social Work, Norwegian University of Science and Technology, N7004 Trondheim, Norway; \\ anita.s.storhaug@ntnu.no \\ * Correspondence: bente.h.kojan@ntnu.no; Tel.: +47-9322-8223
}

Received: 30 June 2018; Accepted: 23 August 2018; Published: 28 August 2018

check for updates

\begin{abstract}
By the end of the 20th century, social class appeared to be an old-fashioned and outdated concept. Serious doubts were expressed about the theoretical and empirical relevance of social class in understanding inequalities in contemporary society. However, experiences from completing research with children and families receiving support from child welfare services shows that applying a class perspective is useful. The purpose of our study was to explore the redistributive and cultural dimensions of social class in the context of child welfare. The data include survey interviews with 715 families in contact with the Norwegian child welfare services (CWS). We found that social class is important but with different effects compared with the industrial society. Our analysis highlighted the problems children and families involved with CWS face, associated with social inequalities based on class differences. We argue that social class is part of the social dynamic of late modern societies, and that this dynamic intertwines with the lives of families in CWS and the problem complexes they encounter in everyday life.
\end{abstract}

Keywords: child welfare; child protection; social class; European Socioeconomic Classification (ESeC); marginalization; redistribution; recognition

\section{Introduction}

Since the 1980s, prominent social scientists declared that social class no longer captured important aspects of social development. Theories of reflexive modernity and additional concepts like de-traditionalisation, choice biography, and fateful moments described a society with more fine-grained inequalities than class analysis could (Beck 1986; Giddens 1991; Beck et al. 1994). However, empirical studies applying a class perspective have shown that social inequality still has an important impact on families and children's lives (Lareau 2002, 2011; Sayer 2005; Elstad and Stefansen 2014; Jarness 2015). In a context of multiple choice, social class is still an important element in the structuring of people's opportunities and individual choices (Giddens 1991; Fauske 1996; Atkinson 2007).

In a post-traditional knowledge society, social class may be analysed in relation to a concept of marginalization. Marginalization is widely used in psychology and sociology to analyse social inequalities. Park introduced the concept in the 1920s as an analytical tool to analyse migrants' experiences of living between cultures (Messiou 2017). One useful definition of marginalization was provided by Dickie-Clark (1966) definition of marginal situations. He linked marginal situations to social and cultural hierarchies in society. Marginalization makes sense in relation to the boundaries drawn in a society. This can be cultural boundaries; boundaries associated with participation in social networks, in education, and in working life; or in lifestyle and knowledge. Thus, attention has also been directed to the actual boundaries and to what is defined as being central or peripheral. Such a 
constraint can be seen in the context of structural changes in society, among other things associated with the transition from an industrial society to a knowledge society. This transition creates new demands on families in terms of participation in different areas, value orientations, and lifestyles. The power of boundary drawing, or to use Bourdieu (1985) term, it also creates languages and symbols that marginalize social groups. Such an understanding of marginalization aligns on several points with Bourdieu's further development of Weber's distinction between class and status groups, which is a distinction between the material and the symbolic. For Bourdieu, class and status are connected in social practices assigned different symbolic meaning (Bourdieu 1985, pp. 4-6). These social practices are also restricted by different forms of capital. As Bourdieu shows, in addition to economic capital, both social and cultural capital are class-based distinctions (Bourdieu 1983).

In this paper, class is explored through the theoretical lens of recognition. We apply a theory of redistribution and recognition to analyse both marginal living conditions and how these conditions are experienced and valued by the families themselves (Fraser 2007; Fraser and Honneth 2003; Honneth 1995). This framework might provide a useful analytical tool in understanding the implications of social class, marginalization, and recognition in a child welfare context (Rossiter 2014; Warming 2015). Fraser (2007) pointed out the importance of paying special attention to redistribution. Honneth (1995) argued for the need for a social policy that protects cultural values, practices, and beliefs about the good (Fjørtoft 2009). Analytical reasons justify considering distribution rights as a different type of injustice other than cultural injustice that must be emphasised separately; although, they can act simultaneously. Social class and marginalization understood materially as living conditions and symbolic as lifestyle, knowledge, and understanding, are relevant perspectives in the analysis of children and families in child welfare, since the problems are complex and are associated with material cues, lifestyle, and mastering the knowledge society's codes on care and parenting practices.

The focus of this paper is the intertwining issues on social class, marginalization, and recognition among families who receive help from child welfare services (CWS). Our contribution is an empirical exploration on how social class and child welfare associate with the dimensions of redistribution and recognition. Thus, we address the dichotomy of whether inequalities are essentially about inequalities in the distribution of social and economic benefits or if they are absence of recognition and violation of those who have different opinions or practices from what is common in society (Fraser and Honneth 2003).

The research questions we explore are:

(1) What is the social class of families in Norwegian Child Welfare who are overrepresented compared to the general population?

(2) What characterizes various social classes in CWS in terms of how they initiated contact and to what degree they were involved in the referral phase?

(3) How does social class and marginalization come to matter as regards parents' experiences of being recognized by the CWS? What associations can be found between social class, marginalization, and recognition?

\subsection{The Norwegian Context}

From an international and comparative perspective, Norway is an egalitarian society (OECD 2017). Equal opportunities, rights, and obligations to participate in society and use its resources irrespective of the economic and social background have been, and still are, central policy goals. Favorable economic conditions have made it possible to succeed in reaching these goals. Employing active social and economic policies, the Nordic welfare model has proven to be successful in producing social equality (Gooby-Taylor et al. 2018).

However, as Esping-Andersen (1999) argued, high levels of equality were primarily achieved after the 1960s. In other words, the Nordic welfare model with high levels of equality is a recent phenomenon. Equalizing incomes mainly resulted from raising the incomes of those at the lower end of the socio-economic ladder. In the late 1970s and early 1980s, another pattern emerged. The trends 
showed a widening gap between rich and poor, and by the turn of the century, the pattern was more widespread. Income inequality has risen significantly, even in Norway and other Nordic countries. In fact, the Nordic countries were among the countries where inequality grew more than anywhere else in the 2000s (OECD 2011, p. 22; OECD 2016).

In 2018, the population in Norway is approximately 5.3 million, and $17.3 \%$ of the total population are immigrants or Norwegian-born to immigrant parents (Statistics Norway 2018a). Although most people in Norway have experienced a considerable increase in personal wealth and living conditions, a growing number of young people and families, many of them with children, have not benefitted from this development. In 2015, almost $11.9 \%$ of all children under 18 years old (134,000 children) in Norway were living in households defined as "at risk of poverty" by the EU's poverty measurement standard, i.e., below $60 \%$ of the median equalized household disposable income. Employment status and family structure explain most of the income inequalities between households. Single-parent families, certain immigrant groups, and households without working adults are overrepresented among those with persistent low income. Many of these families receive benefits from the public and support from child welfare services (Fløtten 2017).

\subsection{Norwegian Child Welfare Services}

The Norwegian Child Welfare Services (CWS) has a long history, starting with the Norwegian Guardianship Act introduced in 1896. Since then, much has changed, and from the end of the 1980s until the present, the Norwegian CWS has experienced a considerable increase in service demands. However, since 2014, the increase has been less distinct (Statistics Norway 2018b).

Some important system orientation differences exist between the Norwegian CWS system and some of the Anglophone systems (Kojan and Lonne 2012). In Norway, the threshold is low for reporting concerns about children to CWS. The CWS emphasizes supportive measures; hence, the risk orientation is not as strong as in more child protection (CP)-oriented systems. In this context, the Norwegian CWS has often been characterized as being family service-oriented (Clifford et al. 2015). The most important evidence for this is the extensive use of supportive services within the family's homes. About $60 \%$ of the children in contact with CWS receive supportive services while living in their biological family homes, $20 \%$ are placed voluntarily in foster or residential care, and $20 \%$ are placed in out-of-home care without the approval of their parents (Statistics Norway 2018b).

Skivenes (2011) argued that the system has a family-sensitive and therapeutic approach to families and children. Over time, the system has developed in a more child-centered direction, with a strong focus on early intervention and prevention, and an increased amount of help for children aged 0-2 years. Like many other Western Child Protection systems, children's needs and life chances are often psychologically understood and assessed in the Norwegian CWS (Andenæs 2004; Bywaters et al. 2015; Kojan and Fauske 2011; Featherstone et al. 2014; Hennum 2016; Wastell and White 2017). Consequently, less attention is paid to the social and economic situation of the families.

Nevertheless, the CWS in Norway still has a significant public role and considerable responsibility for supporting vulnerable families. The current CW Act from 1992 promotes equal living opportunities for children as one of the mandates of the CWS. As such, needing protection is not necessary for accessing child welfare support services. However, a new CW Act outlined in a government report (NOU 2016, p. 16) suggested narrowing the general preventive role of the CWS.

The Norwegian CWS share some important characteristics with other Child Protection Systems: Families in contact with child protection often have severely deficient social lives and struggle with marginalization on informal and formal life areas, such as family, friends, neighbor relations, school and higher education, work, and housing. The needs and life situation of the children and families involved in Child Welfare have many common aspects across child welfare/protection systems. In other words, sound evidence supports the clear social inequalities between families in CWS and those who are not. Consequently, applying a social class perspective on the families in child welfare is highly relevant. 


\section{Materials and Methods}

\subsection{New Child Welfare Services}

The research project The New Child Welfare was a five-year project in which families in contact with Norwegian Child Welfare Services were interviewed. The new child welfare that emerged after 1990 was characterised by more use of family support and needs orientation rather than risk orientation. This refocusing of CWS called for research-based knowledge about children and their families. One of the main objectives of the project was to capture and understand the needs and perspectives of families involved with the CWS in Norway. Based on a questionnaire covering the same areas as the Common Assessment Framework (CAF) and some other topics, 715 families were interviewed in the first wave, in the years 2008-2009. In 16\% of the families, the parents, either one or both, were immigrants.

The survey instrument included questions relating to parents' experience with child welfare, their assessment of their children, the family's and their own situation, as well as information about living standards, income, housing, health, and contact with a variety of helping agencies. A second wave of the study was conducted in 2010-2012. A total of 96 families from the original sample participated. In this analysis, data were applied from the first wave. All subjects provided their informed consent for inclusion before participating in the study, and the approvals were obtained by the research team. The study was approved by the Norwegian Centre for research data.

SPSS 24 was used to analyse the data. The data were facilitated with constructions of indexes of marginalization and experienced recognition. Additionally, social class was operationalised using European Socioeconomic Classification (ESeC). Correspondence analysis, which is an exploratory data technique, was used to analyse the associations between social class, marginalization, and recognition.

\subsection{Study Measures}

\subsubsection{Social Class}

An important part of the research project was to explore the interplay between Child Welfare interventions and social inequality. A class analysis based on the European Socioeconomic Classification (ESeC) was performed. ESeC is a social class schema based on the concept of employment relations, and it is well suited to operationalise social inequality.

ESeC is based on the Erikson-Goldthorpe-Portocarero Form (EGP) (Erikson and Goldthorpe 1992) and is one of the most-used class forms in Europe. The form aims at "measuring and displaying structured socio-economic inequalities and the relationships between socioeconomic position and life-chances" (Rose et al. 2001, p. 1). In ESeC, a class is defined by occupational affiliation. In the operationalisation of the social class of the parents we interviewed, we used Statistics Norway's Standard for Occupational Classification, which is based on the International Occupational Classification ISCO-88 (COM). The occupations are defined based on the tasks and duties undertaken in the job; the trade, profession, or type of work performed by the individual; and degree of autonomy in the employment regulation. Those who are unemployed are separated into another category.

The parent who answered the survey (the mother or father of the child who was registered as a client in the CWS) was asked to provide the occupational affiliation to either "biological father of the child" and "biological mother of the child". Information about occupation was then coded in the survey with the Code of Standard for Occupational Classification. Next, the codes were modified into classes as specified in ESeC. In our analysis, we applied four classes: (1) Salariat (service relationship): Large employers, higher-grade professional, administrative and managerial occupations, lower-grade professional, administrative and managerial occupations, and higher-grade technician and supervisory occupations. (2) Intermediate (mixed service relationship/labor contract): Higher-grade white collar workers, small employer and self-employed occupations (excluding agriculture, etc.), petit bourgeoisie or independents, lower supervisory and lower technician occupations, and higher-grade blue collar workers. (3) Working class (labor contract): Lower services, sales and clerical occupations, lower-grade 
white collar workers, lower technical occupations, skilled workers, routine occupations, and semiand unskilled workers. (4) Unemployed: Those who have never worked or those who experience long-term unemployment, including students.

\subsubsection{Marginalization Index}

To explore the association between social class and marginalization, we developed an additive marginalization index. The index contains living conditions items such as education, work, income, housing, health, substance abuse, residence time in Norway, and Norwegian language skills. The combination of items in the index captures the quantitative dimension of marginalization and sheds light on the social situation of the family.

\subsubsection{Recognition Index}

Based on the parents' answers to open questions about how they experienced the first contact with the child welfare service, it was possible to interpret the answers in relation to whether they felt they were taken seriously by the child welfare services, whether they were "seen", and whether their views were heard. The answers were categorised according to positive or negative experiences with their interaction with the child welfare workers. The parents' experiences were interpreted in terms of how their own views were recognized and valued (Thrana and Fauske 2014).

\subsection{Study Limitations}

The data used in this analysis were cross-sectional, which means the data do not provide a good picture or impression of the families' development over time. Moreover, the data were collected in 2008 and 2009. Although the data were collected nearly 10 years prior to this report, and although the Norwegian population has become more diverse in terms of immigration since, we consider the data reliable for the purpose of our analysis. We know from longitudinal studies using aggregated data that the socio-economic status of the families in child welfare has changed little since the late 1980s (Clifford et al. 2015; Clausen and Kristofersen 2008; Kristofersen 2018).

\section{Results}

\subsection{Social Class of Families in Contact with Child Welfare}

To indicate how and to what extent different social classes are over- or under-represented in the CWS, we accessed social class data about the general population in Norway (aged 20-59 years) from the European Social Survey.

As Table 1 shows, a significant and large class difference existed between the general population in Norway and the CW clientele. The proportion of salariat families was 2.6 times as high in the general population compared with the child welfare population. Families with parents who were unemployed or for the most part unemployed were over-represented in child welfare. However, although salariat and intermediate families were under-represented, they accounted for closer to a third of all families provided with help from CWS. Parents belonging to the service class were under-represented among the families in child welfare, but the proportion of $18 \%$ still represented a significant number of children. Families from all classes received assistance from child welfare, but social classes seem to be an indicator of the risk of problems that trigger child welfare measures.

Further, we found clear sex distinctions between the social class affiliations of mothers and fathers in child welfare. A significant proportion of fathers had working class occupations, and we found that nearly a third of the mothers were unemployed.

Our data provide an impression of how long the families had been in the child welfare system, and that those who belonged to the two lowest class categories were over-represented among families who have been in contact with the CWS for more than five years. This suggests that their problems are of such a nature that they demand interventions from the CWS for an extended period, but we also 
found that these families started to be involved with the CWS at an earlier stage than intermediate and salariat families (Kojan and Fauske 2011).

Table 1. Social class of families in contact with child welfare services compared to the general population (\%).

\begin{tabular}{lllll}
\hline & \multicolumn{2}{l}{ Survey Data New Child Welfare Services } & European Social Survey * \\
\hline Social Class & Mother & Father & Parents ** & Parents Aged 20-59 years \\
\hline Salariat & 13 & 14 & 18 & 47 \\
Intermediate & 11 & 10 & 12 & 18 \\
Working class & 47 & 51 & 50 & 25 \\
Unemployed & 29 & 15 & 20 & 9 \\
Sum per cent & 100 & 100 & 100 & 100 \\
Number & 664 & 572 & 707 & 544
\end{tabular}

* Data accessed from European Social Survey, 2010. ${ }^{* *}$ The class operationalisation is based on the parent with the highest social class.

\subsection{How and Why Families Came into Contact with Child Welfare Services}

Social class appears to be important for the course of the families' contact with child welfare services. We examined how the initial contact between the CWS and the families was established, and analysed the reasons why the families were referred to, or took the initiative to contact, CWS.

In terms of the decision-making process, the analysis showed that parents from the salariat were more involved and agreed to a greater extent with the decisions that were made compared with working class and non-employed parents. Nearly $40 \%$ of the families from the salariat were involved in the first contact with the CWS. Only $25 \%$ of the non-employed families referred themselves or knew that CWS was notified about a concern. The unemployed were, to a greater extent, referred by someone else. They were also more likely to not be informed beforehand about the referral.

\subsection{Social Class and Marginalization}

Social class alone is not always an indicator of the social situation and the well-being of the family. Consequently, we supplemented our findings with other variables that provide information about the family's situation. In the survey, several variables provide additional information (Section 2.2.2). As can be seen from the correspondence analysis in Figure 1, a clear association exists between social class and marginalization.

Figure 1 shows the relationship between the categories of the social class variable and the degree of marginalization. As shown, the categories "working class" and "unemployed" experienced medium and high levels of marginalization, whereas the categories "intermediate" and "salariat" displayed a low degree of marginalization. No clear distinction was observed between the "intermediate class" and "the salariat".

A closer examination of the relationship between marginalization and other factors highlighted associations between social class, parental integration in social areas, and whether there was one or two parents in the household. The number of children in the family had no significant impact. In other words, whether there was one or two incomes in the household was what mattered. A significant difference was also observed between immigrant parents' and Norwegian born parents' income and social integration, but no significant difference was recorded between their scores on the marginalization index. 


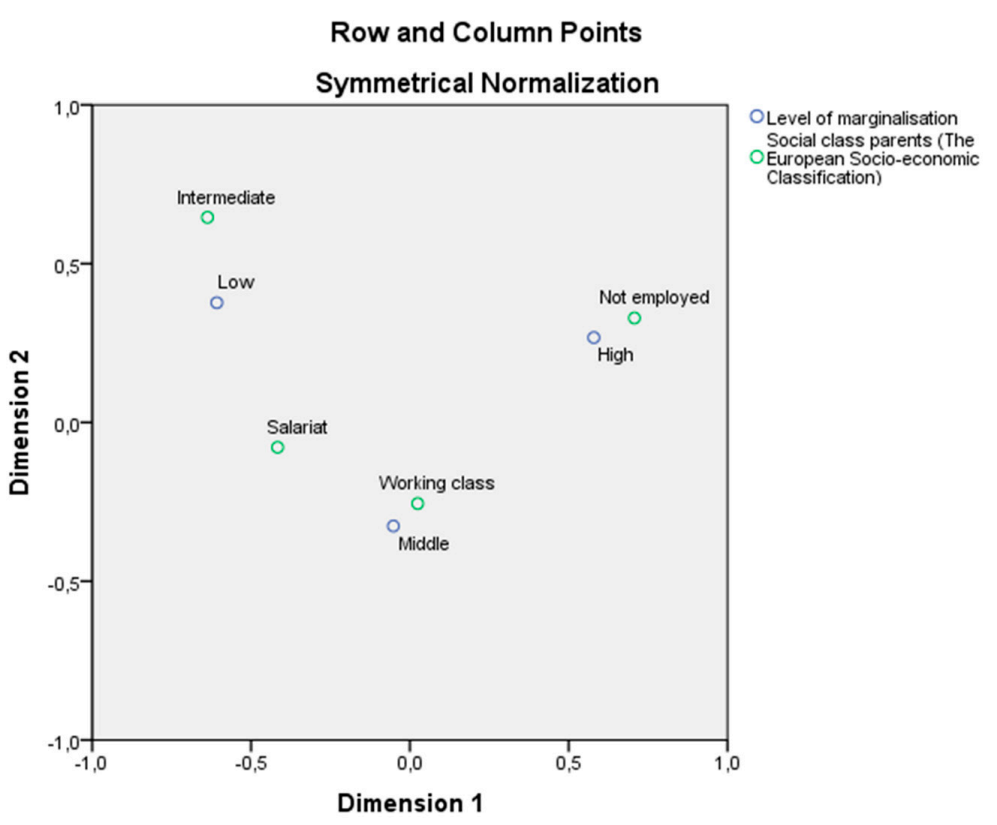

Figure 1. Association between social class and marginalization.

\subsection{Marginalization and Recognition}

In the analysis, we developed an index of recognition (Section 2.2.3). Parents' description of their meeting with child welfare can be interpreted as an experience of recognition or non-recognition (Thrana and Fauske 2014). Marginalization is also associated with recognition of knowledge, views, and social practices.

Figure 2 depicts the association between different degrees of marginalization and the experience of recognition. Parents who are low on marginalization experience recognition. However, parents who score high on marginalization experience a lack of recognition. Those who are classified as an intermediate category of marginalization coincide with an intermediate category of recognition. They partially experience recognition and partly non-recognition.

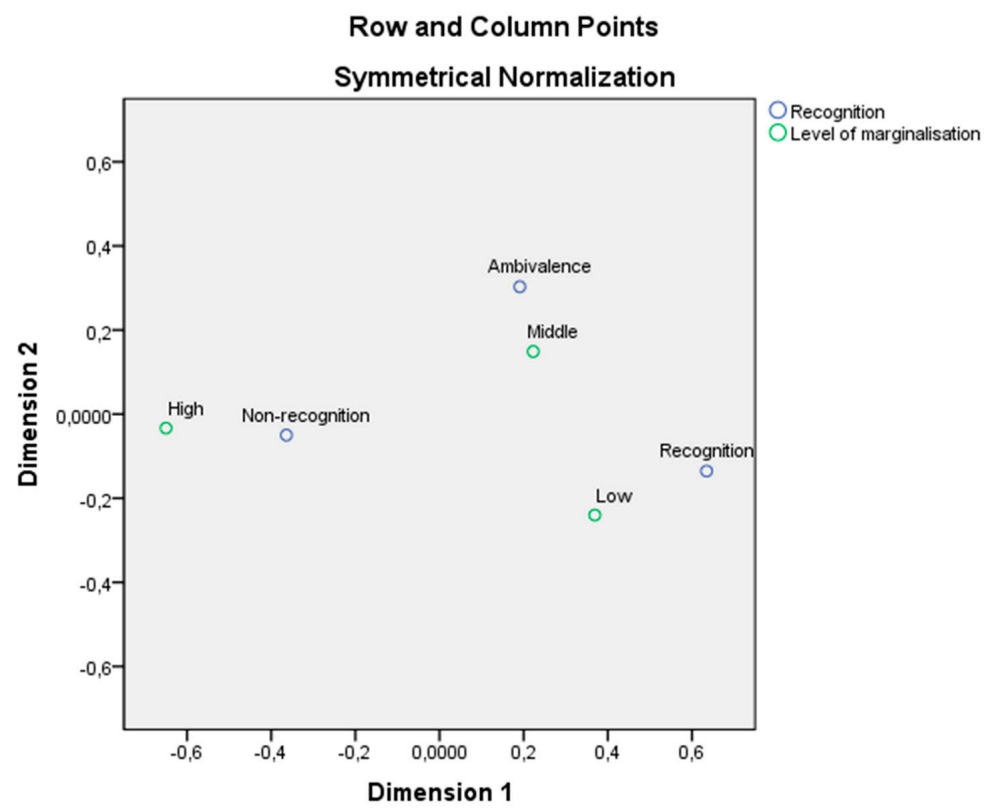

Figure 2. Association between marginalization and parent's experiences of recognition. 
Overall, the analysis showed that the level of marginalization differs between parents who have children who receive help from child welfare services. These parents suffer from different degrees of marginalization, and an association exists between living conditions, marginalization in relation to social networks, and the experience of marginalization in terms of recognition in the meeting with child welfare services. Those who are less marginalised are also less marginalised in relation to all of the abovementioned types of marginalization. Conversely, those who are most marginalized, are most marginalized both in terms of living conditions, social networks, and the experience of being recognized by the child welfare.

\subsection{Marginalization Across Social Classes}

However, our data also showed that some of the families in our sample were marginalized across their social class status (Clifford et al. 2015). Still, the most marginalized were among those who were unemployed. Twice as many as those in the salariat had a high level of marginalization. The mixed data that we obtained from the project showed that the role of social inequality is a complex phenomenon, but still, it is somehow factored into decisions to intervene. This was also evident in the decision-making processes.

In terms of the parents' experience of the decision-making process, we found that parents belonging to the salariat tended to be more positive than unemployed parents. Nearly $40 \%$ of the parents who were unemployed thought that the CWS handled criticism well. Trust directed at child welfare is generally high irrespective of social class, but a tendency was observed here toward lower levels of trust among unemployed parents than for the salariat and the intermediate parents.

\subsection{Summary of Findings}

Our analysis of the families in the CWS display the significant class differences in terms of the high representation of working-class families and families dependent on welfare, particularly their representation in the supportive part of the CWS. However, the analysis also demonstrates class differences between the children in out-of-home care in relation to the type of services provided and the reason for providing these services. We consider the key finding from our analysis to be the close association between the degree of marginalization and recognition; parents who scored low on marginalization experienced recognition and parents who scored high on marginalization experienced to a greater degree a lack of recognition in their meeting with child welfare.

\section{Discussion}

\subsection{Redistribution and Recognition-Intertwining Issues in Child Welfare}

Our analysis showed that the feeling of being recognized is associated with the social class of the family and the degree of marginalization. We found that many of the parents were recognized by child welfare services, revealing a positive picture of how families experience the meeting with the child welfare services. However, a less positive finding was that the most marginalized families experienced a struggle for recognition in their meeting with Child Welfare Services, more so than families with a salariat/intermediate affiliation, who are less marginalized.

Next, we draw upon Bourdieu and the redistribution-recognition controversy to illustrate how social class and recognition might be considered as intertwined issues in understanding how families with various social class affiliations experience their meetings with child welfare. Nonetheless, we argue that it is important that child welfare systems pay attention both to the material and cultural dimensions associated with social class.

Previously, we observed that several types of marginalization are closely linked to each other and that the degree of marginalization corresponds significantly to social class. Additionally, a link between parents' social integration in the community and experienced marginalization exists. This can be understood via Bourdieu (1985) concepts of capital. Our index of marginalization covered social, 
economic, and cultural capital dimensions, and among the parents in child welfare, there is a correlation with all types of capital.

In 2006, Dumbrill (2006, p. 35) stated that child welfare interventions must begin by addressing the power imbalance that exists between worker and client, and by acknowledging the fear parents may be feeling. We agree that acknowledging parents' feelings and emotions is important in child welfare (Tembo and Studsrød 2018). However, it is critical to analyse power imbalances due to economic marginalization. Our analysis has shown that parents' feelings of not being recognized relate to the material, economical, and societal positions of the families. Hence, child welfare workers need to understand that families' struggles for recognition in child welfare are associated with class inequalities. In this connection, the Fraser-Honneth controversy provides a useful tool and critical framework for understanding the connections between social class and recognition in a child welfare context.

Fraser (2007) emphasized the importance of social policies and interventions based on just distribution of material and goods. Honneth (1995) argued for the need for a social policy that protects cultural values, practices, and beliefs. Fraser (Fraser and Honneth 2003) argued that recognition theory has threads for individualisation. In recognition theory, the real problem is often considered the interpersonal relationships, not the social conditions. Fraser and other critics believe that recognition theory is based on traditional attachment theory where problems are psychologised (Garrett 2009; Jordan 2010). Unjust distribution is about marginalization and exclusion in the economic sphere, whereas lack of recognition manifests in terms of social status and representation patterns (Fjørtoft 2009). Recognition may also be seen as an individual appearance of social and cultural hierarchies, and in that sense, is more a cultural than a psychological phenomenon. Fraser emphasised that these two dimensions of injustice require different problem-solving approaches. Economic injustice requires social policy action and redistribution of material goods. Cultural injustice requires measures to change attitudes, values, and norms. Economic redistribution is a little-desired policy in a time that cultivates rationality. Thus, economic redistribution contradicts with the neo-liberal thinking where the goal of social policy is to rationalise and streamline the state's role in the welfare society.

\subsection{Social Class and Power}

This framework is useful to understand that CW families' feeling of being recognized is associated with their social class and the level of marginalization. Following this trait, we will now discuss why this might be so, using previous research on power, authorities, and interactions between professionals and parents. Lareau (2011) explained class differences in terms of how people relate to authorities and professionals. Her findings might provide an important background for understanding the strategies parents use in their meeting with a powerful system such as child welfare services. Economic resources associate with the culture when it comes to how people relate to each other. This can be seen in line with Bourdieu, who stated that a close relationship exists between capital forms, although they are also relatively independent of each other. The social networks are, as he understands it, created through individual or collective "investment strategies" that are deliberately or unconsciously intended to establish or reproduce social relationships that are useful in the short and long term. These networks are maintained over time by the individual obligations and institutional guarantee. A common feature of these networks is that they are exclusive and members contribute to maintaining the boundaries of other networks (Bourdieu 1985, pp. 249-50).

Lareau (2011) reported the working class and unemployed as more "powerless", in the sense that they feel they are in a more vulnerable position, and therefore more hostile in their interactions with authorities. Parents expressed that they did not have the sufficient language when communicating with professionals and expressed constrainment compared to middle-class parents, who were described as more confident and assertive in their interactions with professionals. Middle-class parents also complied more with professional standards and attitudes toward child-rearing. Our analysis showed that working-class and non-employed families felt less recognized by the child welfare services than intermediate and salariat families; however, we do not know if the reason is that these families felt 
more 'powerless' than other families in their meeting with child welfare services. However, a previous analysis (Storhaug and Holtan 2017) showed that working-class and unemployed fathers felt that they were not being heard because they were unable to express themselves clearly and make themselves understood, and because of a lack of what they felt was considered to be appropriate language by professionals. They expressed that child welfare workers tried to transfer their middle-class values and way of living to their families, thus not recognising their values and way of living.

Lareau's study shows how economic resources are associated with cultural resources with regards to how parents relate to authorities, and can contribute to an understanding of the connection between class affiliation and the experience of being recognized by child welfare services. From a professional perspective, social workers may face challenges when helping a child when the family has a style of communicating that deviates from their own (Marthinsen 2003). In other words, the parents express their views and understanding in ways that are not valued by the child welfare workers. For parents, being part of a helping relationship could be difficult when demands are made of communicating differently, for example in the use of interprofessional meetings with several professionals attending. Such settings sometimes construct representation barriers from the child and parent points of views.

From a class perspective, language barriers are also present. The use of terms such as resilience, risk factor, mentalization, disorganized or insecure attachment to describe the problems of the child and parents might strengthen class-related power imbalances (Hennum 2016). Lack of a common language and appropriate communication settings can lead to relationships dominated by uncertainty and mistrust. Reaching a mutual understanding and agreement on the needs and problems of the child and the family might be difficult. Creating a shared understanding of the situation might relate to the experience of whether or not the family feels recognized. The child, parents, and professionals may develop a relationship dominated by mistrust. Such problems might obviously be rooted in intersections of minority status, age, gender as well as social class (Fylkesnes 2018).

\section{Conclusions}

Since the 1980s, psychological theories have dominated child welfare and child protection policies. These theories are often variants of Bowlby (1973) well-known attachment theory. We have also observed epigenetics and neurobiological theories greatly influencing child welfare practices and assessment of parents' care of their children (Wastell and White 2017). Many of the problems and needs of children and families have been explained by attachment disorders and that the children's brain has not developed well due to a poor care environment and damaging parenting practices. The findings from such studies might, of course, be important knowledge for employees in child welfare, but from a class perspective, it may be ethically challenging if these aspects receive too much focus. This might be seen in line with the neo-liberal society, where the focus is shifted from economic redistribution and social policy to a focus on governing identities that, from a professional perspective, quickly focus on disciplining families (Ericsson 2000; Villadsen 2004). Class-based social situations are also an important part of the child's environment and are therefore a context that is relevant both to attachment, parenting styles, and how epigenetics influence child development.

No simple solution can address social class inequalities in child welfare. However, redistribution, recognition, and representation are important aspects, in accordance with Fraser's theory of social justice (Fraser 2007; Fraser and Honneth 2003). These concepts are not new for social work theory, and several voices are suggesting the need for a social and radical change in child welfare (Bywaters et al. 2015; Bywaters and Sparks 2017; Davidson et al. 2017; Gillies et al. 2017; Lonne et al. 2016). Briskman (2017, p. 134) argued that it is necessary to address and manage the harsh neo-liberal policies by addressing social justice and emotions in social work practice.

\section{Addressing Social Class and Recognition in Future Research}

Our analysis highlighted a significant association between social class, marginalization, and the experience of recognition. However, stronger supporting evidence is needed to more thoroughly 
understand these connections. Particularly, exploring parents' experiences and emotions in their meeting with child welfare services from a social class perspective might be valuable. We suggest that important questions to address in future research are: How does social class affect families and influence their contact with social services? How are child welfare families' struggles over recognition associated with class inequalities? How does social class create a barrier in child welfare practice?

Author Contributions: Conceptualization B.H.K. and H.F.; Methodology, H.F. and B.H.K.; Software, H.F. and B.H.K.; Formal Analysis, H.F. and B.H.K.; Investigation, H.F., B.H.K. and A.S.S.; Writing-Original Draft Preparation, B.H.K. and H.F.; Writing-Review \& Editing, B.H.K., H.F. and A.S.S.; Visualization, B.H.K.

Funding: This research was funded by Bufdir.

Conflicts of Interest: The authors declare no conflict of interest.

\section{References}

Andenæs, Agnes. 2004. Hvorfor ser vi ikke fattigdommen? Fra en undersøkelse av barn som blir plassert utenfor hjemmet. Nordisk Sosialt Arbeid 24: 19-33. (In Norwegian)

Atkinson, Will. 2007. Anthony Giddens as adversary of class analysis. Sociology 41: 533-549. [CrossRef]

Beck, Ulrich. 1986. Risikogesellschaft-Auf dem Weg in eine andere Moderne. Franfurt a. M.: Suhrkamp Verlag, ISBN 978-3518113653. (In German)

Beck, Ulrich, Anthony Giddens, and Scott Lash. 1994. Reflexive Modernisation: Politics, Tradition and Aesthetics in the Modern Social Order. Stanford: Stanford University Press, ISBN 9780804724722.

Bourdieu, Pierre. 1983. Ökonomisches Kapital, kulturelles Kapital, sosiales Kapital. In Sosiale Ungleichheiten. Edited by Reinhard Kreckel. Michigan: O. Schwarz \& Company, pp. 183-98. (In German)

Bourdieu, Pierre. 1985. The Forms of Capital. In Handbook of Theory and Research for the Sociology of Education. Edited by John G. Richardson. New York: Greenwood, pp. 241-58. ISBN 9780313235290.

Bowlby, John. 1973. Attachment and Loss. Harmondsworth: Penguin Books.

Bywaters, Paul, and Tim Sparks. 2017. Child protection in England: An emerging inequalities perspective. Journal of Children's Services 12: 107-12. [CrossRef]

Bywaters, Paul, Geraldine Brady, Tim Sparks, Elisabeth Bos, Lisa Bunting, Brigid Daniel, Brid Featherstone, Kate Morris, and Jonathan Scourfield. 2015. Exploring inequities in child welfare and child protection services: Explaining the inverse intervention law. Children and Youth Services Review 57: 98-105. [CrossRef]

Briskman, Linda. 2017. Revitalising radical social work. Aotearoa New Sealand Social Work 29: 133-6. [CrossRef]

Clausen, Stein-Erik, and Lars Bjarne Kristofersen. 2008. Barnevernsklienter i Norge 1990-2005: En Longitudinell Studie. Oslo: NOVA, ISBN 9788278942772. (In Norwegian)

Clifford, Graham, Halvor Fauske, Willy Lichtwarck, and Edgar Marthinsen. 2015. Minst hjelp til dem som trenger det mest? NF-Rapport 6/2015. Bodø: Nordlandsforskning, ISBN 9788273216625. (In Norwegian)

Davidson, Gavin, Lisa Bunting, Paul Bywaters, Brid Featherstone, and Claire McCarten. 2017. Child welfare as justice: Why are we not effectively addressing inequalities? British Journal of Social Work 47: 1641-51. [CrossRef]

Dickie-Clark, Hamish F. 1966. The Marginal Situation. London: Routledge and Kegan Paul.

Dumbrill, Gary. 2006. Parental experience of child protection intervention: A qualitative study. Child Abuse and Neglect 30: 27-37. [CrossRef] [PubMed]

Elstad, Jon Ivar, and Kari Stefansen. 2014. Social Variations in Perceived Parenting Styles among Norwegian Adolescents. Child Indicators Research 3: 649-70. [CrossRef] [PubMed]

Ericsson, Kjersti. 2000. Social control and emancipation-Ambiguities in child welfare. Journal of Scandinavian Studies in Criminology and Crime Prevention 1: 16-26. [CrossRef]

Erikson, Robert, and John Goldthorpe. 1992. The Constant Flux: A Study of Mobility in Industrial Societies. Oxford: Clarendon Press, ISBN 9780198273837.

Esping-Andersen, Gøsta. 1999. Social Foundations of Postindustrial Economies. Oxford: Oxford University Press, ISBN 9780198742005.

Fauske, H. 1996. Changing youth: Transition to adulthood in Norway. Young 4: 47-62. [CrossRef]

Featherstone, Brid, Susan White, and Kate Morris. 2014. Reimagining Child Protection. Towards Humane Social Work with Families. Bristol: Policy Press, ISBN 9781447308010. 
Fjørtoft, Kjersti. 2009. Anerkjennelse i lys av Liberale Rettferdighetsoppfatninger. Norsk Filosofisk Tidsskrift 44: 33-46. (In Norwegian)

Fløtten, Tone. 2017. Den norske modellen i et oppvekstperspektiv, in Bufdir (ed), Oppvekstrapporten 2017. Økte forskjeller—gjør det noe? Oslo: Bufdir, ISBN 9788282863179. (In Norwegian)

Fraser, Nancy. 2007. Reframing justice in a globalizing world. In (Mis)recognition, Social Inequality and Social Justice. Edited by Terry Lovell. Oxon: Routledge, ISBN 9780415464949.

Fraser, Nancy, and Axel Honneth. 2003. Redistribution or Recognition? A Political-philosophical Exchange. London: Verso, ISBN 9781859844922.

Fylkesnes, Marte Knag. 2018. Frykt, forhandlinger og deltakelse: Ungdommer og foreldre med etnisk minoritetsbakgrunn i møte med den norske barnevernstjenesten. Doctoral dissertation, Universitetet $\mathrm{i}$ Bergen, Bergen, Norway.

Garrett, Paul Michael. 2009. Recognizing the limitations of the political theory of recognition: Axel Honneth, Nancy Fraser and Social Work. British Journal of Social Work 40: 1517-33. [CrossRef]

Giddens, Anthony. 1991. Modernity and Self-Identity. Cambridge: Polity Press, ISBN 9780804719438.

Gillies, Val, Rosalind Edwards, and Nicola Horsley. 2017. Challenging the Politics of Early Intervention: Who's Saving Children and Why. Bristol: Policy Press, ISBN 9781447324102.

Gooby-Taylor, Peter, Bjørn Hvinden, Steffen Mau, Benjamin Leruth, Mi Ah Schoyen, and Adrienn Gyory. 2018. Moral economies of the welfare state: A qualitative comparative study. Acta Sociologica. [CrossRef]

Hennum, Nicole. 2016. Kunnskapens makt i beslutninger. In Barnevernets Beslutninger. Edited by Øivin Christiansen and Bente Heggem Kojan. Oslo: Universitetsforlaget, ISBN 9788215026848. (In Norwegian)

Honneth, Axel. 1995. The Struggle for Recognition. The Moral Grammar of Social Conflicts. Cambridge: Polity Press, ISBN 9780262581479.

Jarness, Vegard. 2015. Cultural vs Economic Capital: Symbolic Boundaries within the Middle Class. Sociology 51: 357-73. [CrossRef]

Jordan, Bill. 2010. Why the Third Way Failed: Economics, Morality and the Origins of the Big Society. Bristol: Policy Press, ISBN 9781847426567.

Kojan, Bente Heggem, and Halvor Fauske. 2011. Et klasseperspektiv på barnevernets familier. Tidsskrift for Velferdsforskning 14: 95-109. (In Norwegian)

Kojan, Bente Heggem, and Bob Lonne. 2012. A comparison of systems and outcomes for safeguarding children in Australia and Norway. Child \& Family Social Work 17: 96-107. [CrossRef]

Kristofersen, Lars B. 2018. Regionale variasjoner i barneverntiltak: Et gammelt problem i ny drakt? Fontene Forskning 11: 56-71. (In Norwegian)

Lareau, Anette. 2002. Invisible inequality: Social class and childrearing in black families and white families. American Sociological Review 67: 747-76. [CrossRef]

Lareau, Anette. 2011. Unequal Childhoods: Race, Class, and Family Life, 2nd ed. Berkeley: University of California Press, ISBN 9780520239500.

Lonne, Bob, Maria Harries, Brid Featherstone, and Mel Gray. 2016. Working Ethically in Child Protection. London: Routledge, ISBN 9780415729338.

Marthinsen, Edgar. 2003. Sosialt arbeid og sosial kapital i et senmoderne barnevern. Trondheim: NTNU. (In Norwegian)

Messiou, Kyriaki. 2017. Understanding marginalization through dialogue: A strategy for promoting the inclusion of all students in schools. Educational Review. [CrossRef]

NOU. 2016. Ny barnevernslov. Sikring av barnets rett til omsorg. Oslo: BLD. (In Norwegian)

Rose, David, David Pevalin, Peter Elias, and Jean Martin. 2001. Towards A European Socio-economic Classification: Final Report to Eurostat of the Expert Group. Essex: University of Essex.

OECD. 2011. Divided We Stand Why Inequality Keeps Rising. Available online: http:/ /www.oecd.org/social/ soc/49499779.pdf (accessed on 29 June 2018).

OECD. 2016. Income Inequality Remains High in the Face of Weak. Available online: http://www.oecd.org/ social/inequality-and-poverty.htm (accessed on 1 November 2016).

OECD. 2017. OECD Income Distribution Database (IDD): Gini, Poverty, Income, Methods and Concepts. Available online: http:/ / www.oecd.org/social/income-distribution-database.htm (accessed on 1 May 2018).

Rossiter, Amy. 2014. Axel Honneth's theory of recognition and its potential for aligning social work with social justice. Critical and Radical Social Work 2: 93-108. [CrossRef]

Sayer, Andrew. 2005. The Moral Significance of Class. Cambridge: Cambridge University Press, ISBN 9780521616409. 
Skivenes, Marit. 2011. Norway: Toward A child centric perspective. In Child Protection Systems: International Trends and Emerging Orientations. Edited by Neil Gilbert, Nigel Parton and Marit Skivenes. Oxford: Oxford University Press, pp. 154-79. ISBN 9780199793358.

Statistics Norway. 2018a. Immigrants and Norwegian-born to Immigrant Parents. Available online: https: / / www.ssb.no/en/befolkning/statistikker/innvbef (accessed on 16 July 2018).

Statistics Norway. 2018b. Child Welfare. Available online: https://www.ssb.no/en/sosiale-forhold-ogkriminalitet/statistikker/barneverng/aar (accessed on 29 June 2018).

Thrana, Hilde Marie, and Halvor Fauske. 2014. The emotional encounter with child welfare services: the importance of incorporating the emotional perspective in parent's encounters with child welfare. European Journal of Social Work 17: 221-36. [CrossRef]

Storhaug, Anita S., and Amy Holtan. 2017. Class, gender and marginalization. Paper at The IFSW European Conference: Marginalization and Social Work in a Changing Society, Reykjavik, Iceland, May 28-30.

Tembo, Memory J., and Ingunn Studsrød. 2018. Parents' emotional experiences of their contact with the Child Welfare Services: A synthesis of previous research-A research review. Nordic Social Work Research. [CrossRef]

Villadsen, Kaspar. 2004. Det sociale arbejdes genealogi: Om kampen for at gøre fattige og udstødte til frie mennesker. København: Hans Reitsel Forlag, ISBN 9788741251080. (In Norwegian)

Warming, Hanne. 2015. The life of children in care in Denmark: A struggle over recognition. Childhood 22: $248-62$. [CrossRef]

Wastell, David, and Sue White. 2017. Blinded by Science. The Social Implications of Epigenetics and Neuroscience. Bristol: Policy Press, ISBN 9781447322344.

(C) 2018 by the authors. Licensee MDPI, Basel, Switzerland. This article is an open access article distributed under the terms and conditions of the Creative Commons Attribution (CC BY) license (http:/ / creativecommons.org/licenses/by/4.0/). 